\title{
Shedding of SCD14 by bovine neutrophils following activation with bacterial lipopolysaccharide results in down-regulation of IL-8
}

\author{
Eun J. SOHN ${ }^{\mathrm{a}}$, Max J. PAAPE ${ }^{\mathrm{b} *}$, Douglas D. BANNERMAN ${ }^{\mathrm{b}}$, \\ Erin E. CONNOR ${ }^{\mathrm{b}}$, Raymond H. FETTERER ${ }^{\mathrm{c}}$, Robert R. PETERS ${ }^{\mathrm{a}}$ \\ ${ }^{a}$ Department of Animal and Avian Sciences, University of Maryland, College Park, MD 20742, USA \\ ${ }^{\mathrm{b}}$ Bovine Functional Genomics Laboratory, USDA-ARS, Beltsville, MD 20705, USA \\ ${ }^{c}$ Animal Parasitic Diseases Laboratory, USDA-ARS, Beltsville, MD 20705, USA
}

(Received 1 June 2006; accepted 3 October 2006)

\begin{abstract}
CD14, the leukocyte co-receptor for lipopolysaccharide (LPS), is important in the response of bovine polymorphonuclear neutrophil leukocytes (PMN) to Gram-negative bacteria. In other species, the expression of CD14 on the surface of PMN was shown to increase after exposure to inflammatory stimuli. These newly expressed molecules may originate from either an intracellular pool or through new gene expression. We sought to characterize bovine PMN cell surface expression and shedding of CD14 molecules, and CD14's effect on secretion of the chemoattractants IL- 8 and IL- $1 \beta$ by PMN. Bovine PMN were incubated in RPMI for $20 \mathrm{~h}$ at $37^{\circ} \mathrm{C}$ with LPS $(1,10,100 \mu \mathrm{g} / \mathrm{mL})$. IL-8 release increased with treatment of $1 \mu \mathrm{g} / \mathrm{mL}$ LPS, but decreased 41.5 and $95 \%$ at the 10 and $100 \mu \mathrm{g} / \mathrm{mL}$ concentrations of LPS, respectively. In contrast, shedding of CD14 from the surface of PMN only increased at the highest concentration of LPS $(100 \mu \mathrm{g} / \mathrm{mL})$. Secretion of IL-1 $\beta$ was similar regardless of the LPS concentration used to stimulate PMN. The effect of PMN concentration $\left(1 \times 10^{7}, 2.5 \times 10^{7}, 5 \times 10^{7}\right.$, and $\left.10 \times 10^{7} / \mathrm{mL}\right)$ on CD14 cell surface expression and shedding of IL- 8 and IL-1 $\beta$ were also determined. Shedding of CD14 by PMN increased with increasing concentration of PMN after exposure to 0.1 and $10 \mu \mathrm{g} / \mathrm{mL}$ of LPS, while secretion of IL-8 decreased. IL-1 $\beta$ increased at the highest concentration of PMN. The use of real time polymerase chain reaction showed that CD14 mRNA expression was not different between control and LPS-stimulated cells, indicating that the sCD14 came from either membrane bound CD14 or a preformed pool. Our results demonstrate that release of CD14 from PMN suppresses secretion of IL-8, and may be an important regulatory mechanism for controlling excessive migration of PMN into the bovine mammary gland.
\end{abstract}

CD14 / IL-8 / LPS / neutrophil / bovine

\section{INTRODUCTION}

The recruitment and activation of polymorphonuclear neutrophil leukocytes $(\mathrm{PMN})$ are important for nonspecific host

* Corresponding author:

mpaape@ anri.barc.usda.gov defense against infectious agents [33]. PMN are short-lived blood cells that play a vital role in the inflammatory response. They are one of the first cells recruited to the site of injury or infection. PMN activation results in increased phagocytosis, bacterial killing, release of lysosomal 
enzymes, and generation of superoxide anion [44]. A number of exogenous and endogenous peptide and lipid mediators, such as fMLP, C5a, leukotriene $\mathrm{B}_{4}$ and cytokines (IL-1 $\beta$ and tumor necrosis factor (TNF)- $\alpha$ ) are chemoattractants for PMN [1]. Interleukin (IL)-8 is the best characterized among the PMN attracting chemokines. IL- 8 belongs to the CXC family of chemokines and stimulates PMN adherence, degranulation, respiratory burst and lipid mediator synthesis [31]. Human PMN have been reported to synthesize IL-8, TNF- $\alpha$, IL-1 $\beta$, macrophage-colony stimulating factor (CSF) and granulocyteCSF $[4,5,24]$ and proteases [44].

Many functionally important receptors for microbial ligands on PMN have not yet been identified [29]. Toll-like receptors (TLR) have been identified on mammalian monocytes and PMN. TLR mediate cellular responses to a large array of microbial ligands. TLR-4 is a coreceptor with CD14 for bacterial LPS. CD14 is a glycosylphosphatidyl-inositolanchored protein expressed at high levels on the surface of circulating monocytes and macrophages [8]. An intracellular pool of CD14 exists in bovine PMN and is capable of translocating to the cell surface [27]. A soluble form of CD14, sCD14, is present in bovine serum and milk [23,39]. sCD14 is also present in the plasma membranesecretory vesicles of human PMN [34]. Membrane (m) CD14 and sCD14 function as co-receptors for microbial ligands. sCD14 has two main functions. First, it can facilitate LPS transfer to lipoproteins, preventing over stimulation of the inflammatory response $[20,35]$. Alternatively, it can facilitate LPS binding to cells that do not express CD14 such as endothelial and epithelial cells, and cause activation of TLR-4 and release of cytokines [9].

The objectives of the present study were to: (1) quantify release of sCD14, IL-8 and IL-1 $\beta$ from bovine PMN following stimulation with LPS; (2) determine whether
sCD14 plays a regulatory role in the release of IL- 8 and IL-1 $\beta$; and (3) determine if sCD14 originates from pre-formed molecules or new gene expression.

\section{MATERIALS AND METHODS}

\subsection{Cows}

Thirty-five clinically normal mid- to late-lactating Holstein cows $(220 \pm 60 \mathrm{~d}$ of lactation) were selected from the USDA Beltsville Agricultural Research Center (BARC) dairy herd. The use and care of all animals were approved by the Beltsville Agricultural Research Center's and the University of Maryland Animal Care and Use Committees.

\subsection{Blood sampling and $P M N$ isolation}

Blood was collected from the tail vein by venipuncture in heparinized vacutainer tubes (Becton Dickinson, Franklin Lakes, NJ, USA). PMN were isolated using the procedure of Hahn and Tolle [11]. Briefly, blood was centrifuged at $500 \times g$, for $5 \mathrm{~min}$, at $4{ }^{\circ} \mathrm{C}$. Plasma, buffy coat and $1 / 3$ of the red blood cells (RBC) were removed. The remaining $\mathrm{RBC}$ and white blood cells (WBC) (10 mL) were suspended dropwise into a double volume $(20 \mathrm{~mL})$ of cold $0.2 \% \mathrm{NaCl}$ solution and gently mixed for about $1 \mathrm{~min}$ for lysis of RBC. Immediately, half the original volume of cold $3.7 \% \mathrm{NaCl}$ solution $(5 \mathrm{~mL})$ was added to restore isotonicity. The suspension was centrifuged at $200 \times g$ for $1 \mathrm{~min}$ at $4{ }^{\circ} \mathrm{C}$. The WBC pellet was washed twice with $20 \mathrm{~mL}$ of $0.0132 \mathrm{M}$, $\mathrm{pH} 7.4,0.85 \% \mathrm{NaCl}$ solution (phosphatebuffered saline solution; PBS) (BioWhittaker, Walkersville, MD, USA). Smears were prepared from the pellet on glass microscope slides and stained with Hemacolor (Merck, D-64293 Darmstadt 1, Germany) in an automatic slide stainer (HemaTex 2000, Bayer, Corp. Elkhart, IN, USA). 
Differential microscopic counts were determined by counting 100 cells. Purity of the isolated PMN was 94\%. Viability, as determined by exclusion of trypan blue [32], was $98 \%$.

\subsection{Flow cytometric analysis}

One-million cells in RPMI-1640 (Bio Whittaker) were incubated with $0,1,10$ and $100 \mu \mathrm{g} / \mathrm{mL}$ of LPS derived from Escherichia coli 0111:B4 (Sigma Chemical Co., St. Louis, MO, USA) at $37{ }^{\circ} \mathrm{C}$ for $20 \mathrm{~h}$ in a $5 \% \mathrm{CO}_{2}$ incubator. Then, cells were reacted with anti-rbosCD14 monoclonal antibody (mAb) [39] $(1: 10)$ at $4{ }^{\circ} \mathrm{C}$ for $30 \mathrm{~min}$. The cells were washed $3 \times$ with PBS. Fluorescein isothiocyanate (FITC)labeled affinity- purified antibody to mouse $\operatorname{IgG}+\operatorname{IgM}$ (heavy and light chains, KPL, Gaithersburg, MD, USA) was added at a 1:100 dilution in PBS to cells reacted with $\mathrm{mAb}$, and untreated control cells that were not reacted with $\mathrm{mAb}$. After $30 \mathrm{~min}$ of incubation at $4{ }^{\circ} \mathrm{C}$, the cells were washed $3 \times$ with PBS and resuspended in $200 \mu \mathrm{L}$ PBS. Flow cytometric analysis was performed using a Coulter Epics Profile I-Argon laser flow cytometer (Coulter Electronics Inc., Hialeah, FL, USA). The laser was set at $488 \mathrm{~nm}$ wavelength, 7.0 to $7.5 \mathrm{~A}$ current and $15 \mathrm{~mW}$ power. The laser was aligned by use of fluorospheres (Immuno-Check, Epics alignment fluorospheres, Epics Division, Coulter Corp, Hialeah, FL, USA). Gains for forward-angle light scatter were set at 10 , and logarithmic transformations were used for side $\left(90^{\circ}\right)$ light scatter and for green fluorescence. Locations of the cell populations in dot plots had been determined previously on the basis of analyses of pure populations of leukocytes [15]. A bitmap (electronically defined observation area) was drawn around the PMN. Percentage of cells fluorescing $(\% \mathrm{~F})$ and the level of expression (log mean fluorescent channel, LMFC) were recorded by measuring the green fluorescence associated with the gated cell population.

\subsection{Apoptosis of PMN}

PMN apoptosis was evaluated to determine if apoptosis contributed to the release of CD14 from PMN. After stimulation of PMN for 6 or $20 \mathrm{~h}$ at $37{ }^{\circ} \mathrm{C}$ with either 0 , 1,10 or $100 \mu \mathrm{g} / \mathrm{mL}$ of LPS (Sigma Chemical Co.), apoptosis was quantified using a flow cytometric procedure with staining of phosphatidylserine with a AnnexinV-FLUOS staining kit (Roche, Penzberg, Germany). Flow cytometric analysis was performed as described in the previous section.

\subsection{Release of CD14, IL-8 and IL-1及 from bovine PMN}

To study the effects of LPS, PMN $(5 \times$ $10^{6} / \mathrm{mL}$ ) were cultured with media alone (control) or stimulated with 1,10 and $100 \mu \mathrm{g} / \mathrm{mL}$ of LPS (Sigma Chemical Co.) for either 6 or $20 \mathrm{~h}$ at $37^{\circ} \mathrm{C}$. Supernatants were assayed for IL-8, CD14 and IL-1 $\beta$. A time course study was also conducted to determine the release of CD14 from PMN $\left(5 \times 10^{6} / \mathrm{mL}\right)$ after stimulation with $100 \mu \mathrm{g} / \mathrm{mL}$ of LPS (Sigma Chemical Co.). PMN supernatants were collected before, immediately after and 2, 4, 8 and 16 h relative to stimulation with LPS. Supernatants were assayed for CD14 by ELISA. Further experiments were conducted to determine the effect of PMN concentration and LPS on the release of CD14, IL- 8 and IL-1 $\beta$. To study the effect of cell density, PMN were resuspended in RPMI and plated into 96-well tissue culture plates at $1 \times 10^{7}$, $2.5 \times 10^{7}, 5 \times 10^{7}$ and $10 \times 10^{7} \mathrm{PMN} / \mathrm{mL}$ (200 $\mu \mathrm{L} /$ well), containing 0.1 or $10 \mu \mathrm{g} / \mathrm{mL}$ of LPS. We hypothesized that with higher concentrations of PMN, and correspondingly larger pools of membrane CD14 that could be shed, that lower concentrations of LPS could evoke enough CD14 shedding 
to suppress IL-8 production. The plates were incubated at $37{ }^{\circ} \mathrm{C}$ for $16 \mathrm{~h}$ in a $5 \% \mathrm{CO}_{2}$ incubator. Supernatants were collected by centrifugation at $13000 \times g$ and assayed for IL- 8 and CD14 by ELISA (see below). To study the effects of LPS, PMN $\left(5 \times 10^{6} / \mathrm{mL}\right)$ were cultured with media alone (control) or stimulated with 1, 10 and $100 \mu \mathrm{g} / \mathrm{mL}$ of LPS (Sigma Chemical Co.) for either 6 or $20 \mathrm{~h}$ at $37^{\circ} \mathrm{C}$. Supernatants were assayed for IL-8, CD14 and IL-1 $\beta$.

\subsection{ELISA for CD14, IL-8 and IL-1 $\beta$}

For the CD14 ELISA, flat-bottom 96well plates were coated with $5 \mu \mathrm{g} / \mathrm{mL}$ of mouse anti-rbos CD14 (CAM36A clone; VMRD, Inc., Pullman, WA, USA) diluted in $0.05 \mathrm{M}$ sodium carbonate, $\mathrm{pH} 9.6$ at $4{ }^{\circ} \mathrm{C}$ for $16 \mathrm{~h}$. The plates were washed $4 \times$ with $0.05 \%$ Tween 20 (Sigma Chemical Co.) diluted in $50 \mathrm{mM}$ Tris buffered saline (TBS, Sigma Chemical Co.), pH 8.0, and subsequently blocked with $2 \%$ fish skin gelatin (Sigma Chemical Co.,) for $1 \mathrm{~h}$ at room temperature. Plates were washed $3 \times$ with TBS (Sigma Chemical Co.) and $100 \mu \mathrm{L}$ of supernatant samples were added to each well, incubated for $2 \mathrm{~h}$ at room temperature and washed $3 \times$ with TBS (Sigma Chemical Co.). Rabbit anti-bovine CD14 polyclonal antibody [39] was diluted 1:2000 in TBS containing $0.2 \%$ gelatin (Sigma Chemical Co.), and $100 \mu \mathrm{L}$ was added to each well and subsequently washed as above. One-hundred $\mu \mathrm{L}$ of HRP-conjugated goat anti-rabbit IgG $(\mathrm{H}+\mathrm{L}$; Promega, Madison, WI, USA) diluted (1:5000) in PBS containing $0.2 \%$ gelatin was added to each well. Plates were incubated for $1 \mathrm{~h}$ at room temperature, washed as above, and $100 \mu \mathrm{L}$ of tetramethylbenzidine (TMB, Sigma Chemical Co.) substrate solution added to each well. The reaction was stopped by the addition of $100 \mu \mathrm{L}$ of $2 \mathrm{M} \mathrm{H}_{2} \mathrm{SO}_{4}$ and the absorbance read at $450 \mathrm{~nm}$ on a mi- croplate reader (Bio-Tek Instruments, Inc., Winooski, VT, USA).

For IL-8, supernatants were assayed using a commercially available human IL8 ELISA kit (R\&D Systems, Inc., Minneapolis, MN, USA). The antibody pairs used in this kit have been previously shown to cross-react with bovine IL-8 $[37,38]$. The optical density at $450 \mathrm{~nm}$ and a correction wavelength of $550 \mathrm{~nm}$ was determined on a microplate reader (Bio-Tek Instruments). Values, expressed in $\mathrm{pg} / \mathrm{mL}$, were interpolated from a standard curve of known amounts of human IL-8 using linear regression analysis.

For quantitation of IL-1 $\beta$, flat bottom 96-well plates were coated overnight at $4{ }^{\circ} \mathrm{C}$ with $5 \mu \mathrm{g} / \mathrm{mL}$ of mouse anti-bovine IL-1 $\beta$ (Serotec, Raleigh, NC, USA) antibody. The plates were washed three times with $0.05 \%$ Tween 20 (Sigma Chemical Co.) diluted in $50 \mathrm{mM}$ TBS (Sigma Chemical Co.), pH 8.0, and blocked with $2 \%$ fish skin gelatin (Sigma Chemical Co.) for $1 \mathrm{~h}$ at room temperature. The plates were washed, and $100 \mu \mathrm{L}$ of sample was added to the anti-IL-1 $\beta$ coated plates. Following a 2-h incubation at room temperature, the plates were washed, and $100 \mu \mathrm{L}$ of rabbit polyclonal anti-bovine IL- $1 \beta$ antibody (Serotec) diluted to 1:500 was added. The plates were incubated for $1 \mathrm{~h}$ at room temperature and washed. HRP-conjugated goat anti-rabbit IgG (Promega) was diluted 1:5000 in TBS (Sigma Chemical Co.) wash buffer containing $0.2 \%$ gelatin, and $100 \mu \mathrm{L}$ of this solution was added to each well. The plates were incubated for $30 \mathrm{~min}$ at room temperature and washed. TMB substrate solution (Sigma Chemical Co.) was added to each well. The reaction was stopped by the addition of $100 \mu \mathrm{L}$ of $2 \mathrm{M} \mathrm{H}_{2} \mathrm{SO}_{4}$ and the absorbance was read at $450 \mathrm{~nm}$ on a microplate reader (Bio-Tek Instruments). Values were interpolated from a standard curve of known amounts of ovine IL-1 $\beta$ using linear regression analysis. 


\subsection{LPS stimulation and absolute quantitative real-time PCR}

PMN $\left(5 \times 10^{7}\right)$ isolated from 2 cows were incubated in duplicate for $30 \mathrm{~min}$ at $37^{\circ} \mathrm{C}$ in RPMI 1640 with 0 and $100 \mu \mathrm{g} / \mathrm{mL}$ of LPS to determine the effect of shortterm LPS exposure on CD14 mRNA expression. In a second experiment, PMN $\left(5 \times 10^{7}\right)$ isolated from 3 cows were incubated in duplicate for 0,3 and $6 \mathrm{~h}$ at $37^{\circ} \mathrm{C}$ in RPMI1640 with 0 and $100 \mu \mathrm{g} / \mathrm{mL}$ LPS to determine the effect of LPS treatment on CD14 mRNA expression over time. Total RNA was extracted from individual samples using the RNeasy Mini kit (Qiagen, Valencia, CA, USA). RNA concentration and purity were determined using a NanoDrop ND-1000 spectrophotometer (Nanotech Technologies, Wilmington, DE, USA).

Reverse transcription was conducted using $500 \mathrm{ng}$ of total RNA and the iScript cDNA Synthesis kit (Bio-Rad Laboratories, Hercules, CA, USA) in a $20-\mu \mathrm{L}$ reaction volume according to kit instructions. For each reaction, a parallel negative control reaction was performed in the absence of reverse transcriptase. Subsequent PCR was conducted in duplicate using $12.5 \mu \mathrm{L}$ of iQ SYBR Green Supermix (Bio-Rad Laboratories), $2 \mu \mathrm{L}$ of first strand cDNA and $0.4 \mu \mathrm{M}$ of each primer, in a $25-\mu \mathrm{L}$ reaction volume according to kit instructions. Primer sequences for CD14 were: 5'-CTCCAGCACCAAAATGAC-3' (forward) and 5' -TCCТCTTCCСТCTCTTCC3' (reverse). Thermocycling was performed in the iCycler iQ detection system (Bio-Rad Laboratories) using the following conditions: $95{ }^{\circ} \mathrm{C}$ for $3 \mathrm{~min}$, followed by 45 cycles of $94{ }^{\circ} \mathrm{C}$ for $15 \mathrm{~s}$, $54{ }^{\circ} \mathrm{C}$ for $30 \mathrm{~s}$, and $72{ }^{\circ} \mathrm{C}$ for $30 \mathrm{~s}$ with fluorescence detection during the extension step. Identity of the 145-bp amplification product was confirmed by direct sequencing using a CEQ8000 automated sequencer and DTCS Quickstart chemistry (Beckman Coulter, Inc., Fullerton, CA, USA). Abundance of CD14 transcripts was determined using the iCyler Software from an external standard calibration curve analyzed simultaneously and expressed as the number of CD14 transcripts per $\mu \mathrm{g}$ of total RNA in the reaction. Standards were synthesized from agarose gel-purified CD14 PCR amplification products using the QIAquick Gel Extraction kit (Qiagen), and ranged from 100 to $1 \times 10^{6}$ copies. Amplification efficiencies for all assays were between 87 and $95 \%$ and correlation coefficients were $\geq 0.997 \%$.

\subsection{Statistical methods}

The unpaired or paired sample $t$-test and one way analysis of variance (Prism version 4.0 for Windows; Graph Pad Software Inc., San Diego, CA, USA) were used for the statistical analyses. The Tuckey Test was used to assess individual differences among treatment means. A $P$-value $<0.05$ was considered significant.

\section{RESULTS}

\subsection{Apoptosis of PMN}

To determine if apoptosis contributed to the release of CD14, PMN were exposed to 1,10 and $100 \mu \mathrm{g} / \mathrm{mL}$ of LPS for 6 and $20 \mathrm{~h}$. Apoptosis of bovine PMN was suppressed $(P<0.05)$ after $6 \mathrm{~h}$ of stimulation with all concentrations of LPS (Fig. 1A). The percentage of apoptosis for control PMN averaged $76 \%$ and decreased to $46-50 \%$ after exposure to LPS. After exposure of PMN for $20 \mathrm{~h}$, percentage of apoptosis for control PMN averaged 61\%, and no effect of LPS on apoptosis was observed $(P>$ $0.05)$ when compared to PMN in media alone (Fig. 1B). 
3.2. Surface CD14 receptor expression and release of CD14 after stimulation with LPS

Flow cytometry and FITC-labeled CD14 was used to detect cell surface mCD14. The percentage of PMN expressing mCD14 on the control cells was $35.6 \%$ (Fig. 2A). The percentage of $\mathrm{PMN}$ expressing mCD14 decreased $(P<0.01)$ to $24 \%$ after stimulation with $100 \mu \mathrm{g} / \mathrm{mL}$ of LPS. There was no change

A

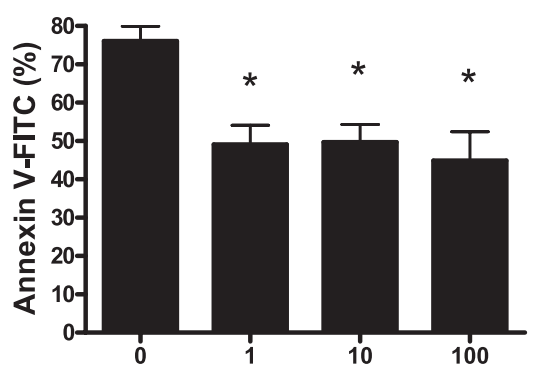

Concentration of LPS $(\mu \mathrm{g} / \mathrm{mL})$

B

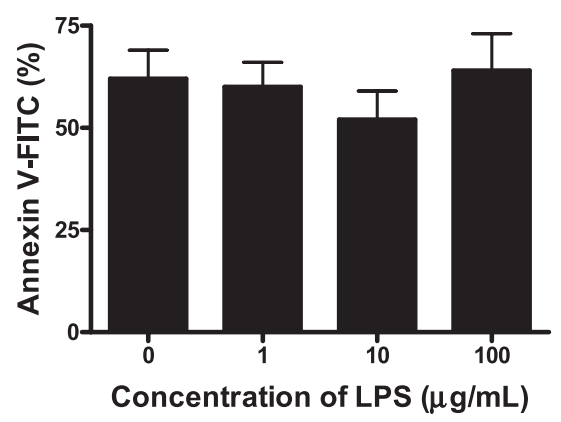

Figure 1. Percentage of apoptotic PMN $(5 \times$ $10^{6} / \mathrm{mL}$ ) isolated from 5 cows following $6 \mathrm{~h}$ (A) or $20 \mathrm{~h}$ (B) of incubation with varying concentrations of LPS. All concentrations of LPS reduced $(P<0.05)$ the percentage of apoptotic PMN after $6 \mathrm{~h}$ of incubation. No change $(P>0.05)$ in apoptosis was observed with LPS after $20 \mathrm{~h}$ of incubation when compared to unstimulated PMN. Means \pm SEM. in the percentage of PMN fluorescing when stimulated with either 1 or $10 \mu \mathrm{g} / \mathrm{mL}$ of LPS when compared to unstimulated controls. There were no changes in the LMFC among the various treatments (data not shown).

An ELISA was used to detect CD14 in PMN supernatants after stimulation with $\operatorname{LPS}(0,1,10$ or $100 \mu \mathrm{g} / \mathrm{mL})$ for

A

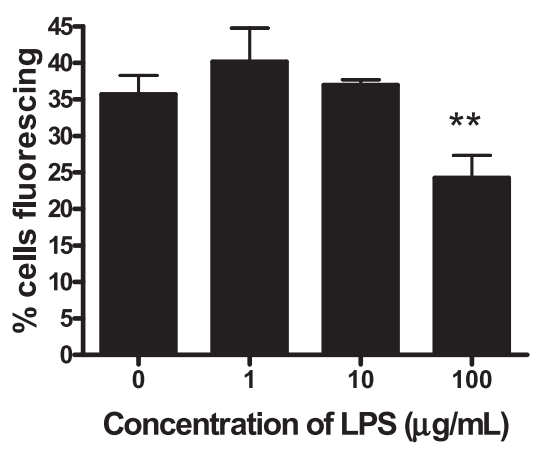

B

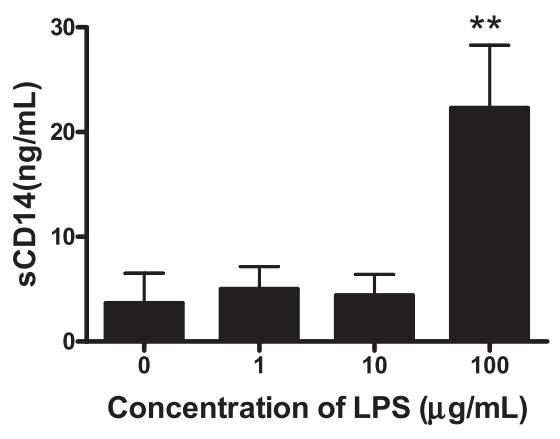

Figure 2. Effect of different concentrations of LPS on release of CD14 from PMN $(1 \times$ $10^{6} / \mathrm{mL}$ ) after incubation at $37{ }^{\circ} \mathrm{C}$ for $20 \mathrm{~h}$. (A) Exposure to $100 \mu \mathrm{g} / \mathrm{mL}$ LPS decreased the percentage of PMN isolated from 5 cows expressing $\mathrm{mCD} 14$, as determined by flow cytometry, and $(\mathbf{B})$ increased the release of CD14 into PMN $\left(5 \times 10^{6} / \mathrm{mL}\right)$ supernatants $(n=4$ cows), as determined by ELISA, when compared to unstimulated PMN or PMN stimulated with 1 and $10 \mu \mathrm{g} \operatorname{LPS}(* * P<0.01)$. Means \pm SEM. 


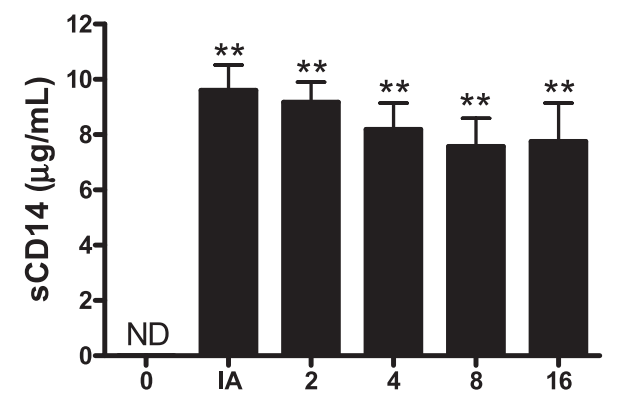

Time After Stimulation with LPS (h)

Figure 3. Concentration of sCD14 in PMN supernatants before $(0 \mathrm{~h})$, immediately after (IA) and 2, 4, 8, and $16 \mathrm{~h}$ after stimulation of PMN $\left(5 \times 10^{6} / \mathrm{mL}\right)$ isolated from 5 cows with $100 \mu \mathrm{g} / \mathrm{mL}$ of LPS. Values differ from unstimulated PMN (** $P<0.01)$. ND $=$ Not detected. Means \pm SEM.

$20 \mathrm{~h}$ at $37{ }^{\circ} \mathrm{C}$. PMN released CD14 $(22 \pm 8.8 \mathrm{ng} / \mathrm{mL})$ after stimulation with $100 \mu \mathrm{g} / \mathrm{mL}$ of LPS when compared to unstimulated PMN $(P<0.01)$ (Fig. 2B), and reflected the decrease in the percentage of PMN expressing CD14 on their surface after exposure to $100 \mu \mathrm{g} / \mathrm{mL}$ of LPS (Fig. 2A). No significant release was observed for PMN stimulated with either 1 or $10 \mu \mathrm{g} / \mathrm{mL}$ of LPS when compared to control media.

\subsection{Release of sCD14 from PMN over time after LPS stimulation}

In a follow-up time course study (Fig. 3), an increase $(P<0.01)$ in the release of sCD14 was observed immediately after (IA) the addition of $100 \mu \mathrm{g} / \mathrm{mL}$ LPS, and did not change throughout the $16 \mathrm{~h}$ incubation period. sCD14 was not detected in the PMN supernatants collected before (time 0) stimulation with LPS.

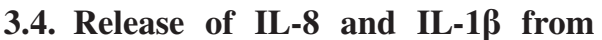 PMN after LPS stimulation}

To investigate release of IL-8, PMN ( $5 \times$ $10^{6} / \mathrm{mL}$ ) were incubated for $20 \mathrm{~h}$ at $37^{\circ} \mathrm{C}$

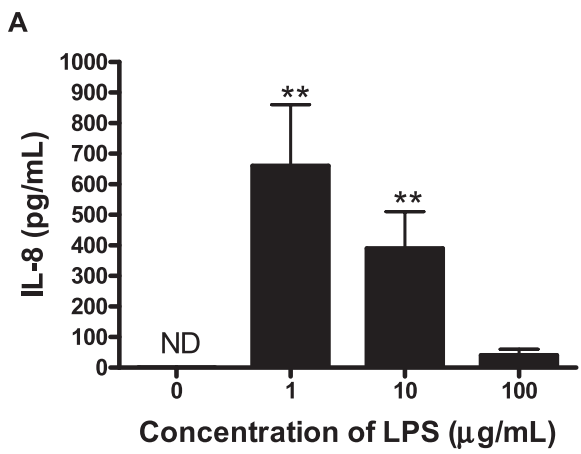

B

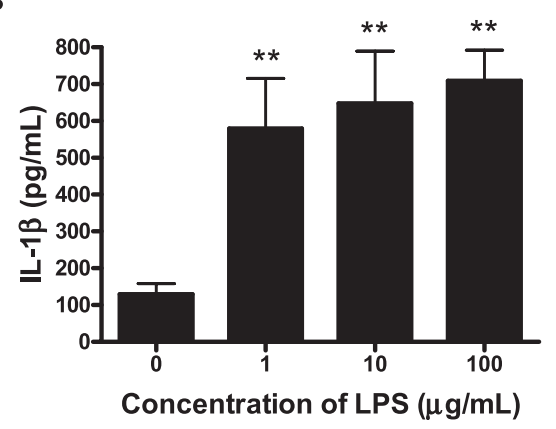

Figure 4. Release of IL- 8 and IL- $1 \beta$, as determined by ELISA, from PMN $\left(5 \times 10^{6} / \mathrm{mL}\right)$ isolated from 5 cows after $20 \mathrm{~h}$ of incubation with different concentrations of LPS. (A) 1 and $10 \mu \mathrm{g}$ of LPS induced release of IL-8 from PMN. Values differ from unstimulated PMN (** $P<0.01)$. ND $=$ Not detected. $(\mathbf{B})$ All concentrations of LPS induced release of IL$1 \beta$ when compared to unstimulated PMN $(P<$ $0.01)$. Means \pm SEM.

with different concentrations of LPS $(0$, 1, $10,100 \mu \mathrm{g} / \mathrm{mL})$. IL-8 secretion from $\mathrm{PMN}$ was greatest $(670.4 \mathrm{pg} / \mathrm{mL} \pm 210.2$ $\mathrm{pg} / \mathrm{mL}$ ) at a concentration of $1 \mu \mathrm{g} / \mathrm{mL}$ of LPS (Fig. 4A). Incubation of PMN with 10 and $100 \mu \mathrm{g} / \mathrm{mL}$ LPS decreased IL-8 secretion 41.5 and $95 \%$ when compared to $1 \mu \mathrm{g} / \mathrm{mL}$ of LPS. IL-8 was not detected in supernatants from unstimulated PMN and did not differ from the amount detected after stimulation with $100 \mu \mathrm{g} / \mathrm{mL}$ LPS. IL- $1 \beta$ increased $(P<0.01)$ after stimulation with 
all three concentrations of LPS when compared to media controls (Fig. 4B). All three concentrations of LPS evoked similar increases in IL-1 $\beta(P>0.05)$.

\subsection{Effect of PMN concentration on release of SCD14, IL-8 and IL-1 $\beta$}

To investigate the inhibitory effect of sCD14 on LPS-induced PMN release of IL-8 and IL- $1 \beta$, varying concentrations of PMN were stimulated for $16 \mathrm{~h}$ at $37{ }^{\circ} \mathrm{C}$ with either 0.1 or $10 \mu \mathrm{g} / \mathrm{mL}$ LPS. For both concentrations of LPS, as the release of sCD14 increased with increasing concentration of PMN (Figs. 5A and 6A), the release of IL-8 decreased (Figs. 5B and 6B). As depicted in Figure $5 \mathrm{~A}$, secretion of sCD14 after stimulation with $0.1 \mu \mathrm{g}$ of LPS increased at the higher cell densities when compared to a cell density of $1 \times 10^{7} / \mathrm{mL}$. The increase in sCD14 inhibited release of IL-8from PMN after stimulation with $0.1 \mu \mathrm{g} / \mathrm{mL}$ of LPS (Fig. 5B). The same inhibitory effect of sCD14 on IL-8 release was also observed when PMN were stimulated with $10 \mu \mathrm{g} / \mathrm{mL}$ LPS (Figs. 6A and B).

\subsection{Expression of intracellular CD14}

Abundance of CD14 transcripts in bovine PMN was determined by absolute quantitative real-time PCR, and expressed as the number of transcripts per $\mu \mathrm{g}$ of total RNA in the PCR reaction. We observed no increase $(P>0.05)$ in CD14 expression when PMN were exposed for $30 \mathrm{~min}$ to $100 \mu \mathrm{g} / \mathrm{mL}$ LPS relative to control PMN (Fig. 7A). Likewise, in a more extended time course, there was no increase $(P>$ $0.05)$ in CD14 transcript abundance in LPS-treated PMN relative to controls after 0,3 or $6 \mathrm{~h}$ of treatment (Fig. 7B).

\section{DISCUSSION}

Contribution of PMN to host defense and natural immunity extend well beyond
A

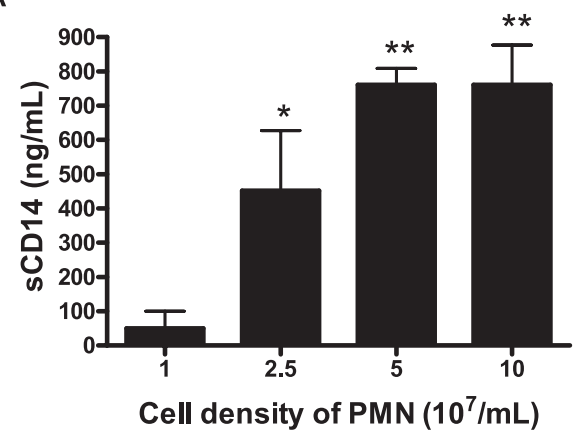

B

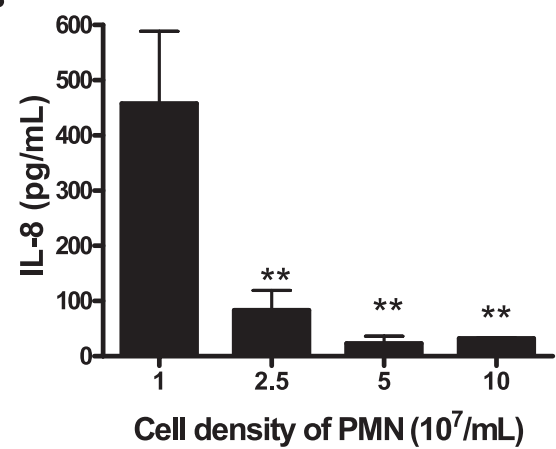

Figure 5. Effect of PMN concentration $(n=5$ cows) on release of SCD14 (A) and IL-8 (B) in response to $0.1 \mu \mathrm{g} / \mathrm{mL}$ LPS. Values differ from $1 \times 10^{7} \mathrm{PMN} / \mathrm{mL}(* P<0.05, * * P<0.01)$. Means \pm SEM.

their traditional role as professional phagocytes. PMN serve as the first immunological defense against invading bacteria and are key players in both the innate and acquired immune responses. Early recruitment of PMN is important for rapid clearance of bacteria and resolution of infection $[2,36,37]$. The role of sCD14 in the rapid recruitment of bovine PMN has been recently studied. The gene responsible for production of bovine CD14 has been cloned [42], and a baculovirus containing the $\mathrm{N}$-terminal $1-358$ amino acids of bovine CD14 (rbosCD14) was generated and used to infect insect sf9 cells from which the rbosCD14 was 
A

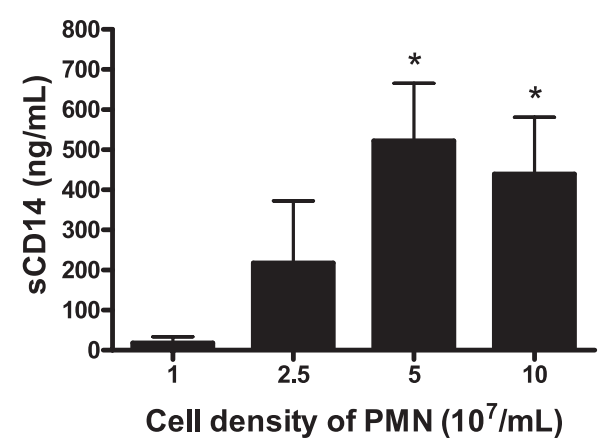

B

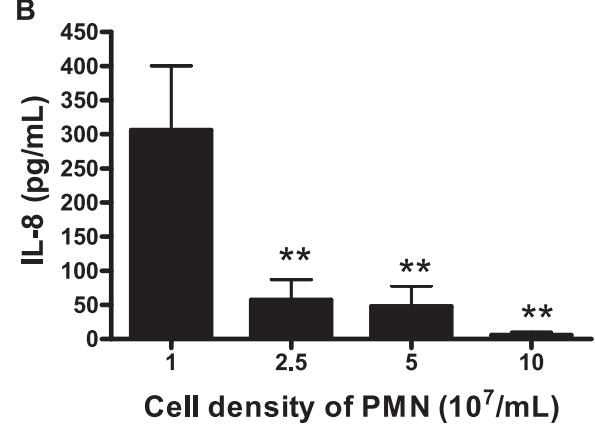

Figure 6. Effect of PMN concentration ( $n=4$ cows) on release of sCD14 (A) and IL-8 (B) in response to $10 \mu \mathrm{g} / \mathrm{mL}$ of LPS after incubation for $16 \mathrm{~h}$ at $37^{\circ} \mathrm{C}$. (A) Values differ from $1 \times$ $10^{7} / \mathrm{mL}(* P<0.05)$. (B) Values differ from $1 \times 10^{7} / \mathrm{mL}(* * P<0.01)$.

purified. Recently, rbosCD14 was directly cloned into a plant virus, and used to infect tobacco plants [25]. The plant-derived sCD14 (PrbosCD14) was purified from plant extracts. Both the rbosCD14 and PrbosCD14 showed good biological activity in dairy cows. When both recombinant proteins were individually combined with LPS and injected into udders of lactating dairy cows, the resulting increase in milk somatic cells for mammary quarters receiving the recombinant proteins and LPS were greater compared to somatic cell counts for quarters injected with just LPS [18, 25,41]. Further,
A

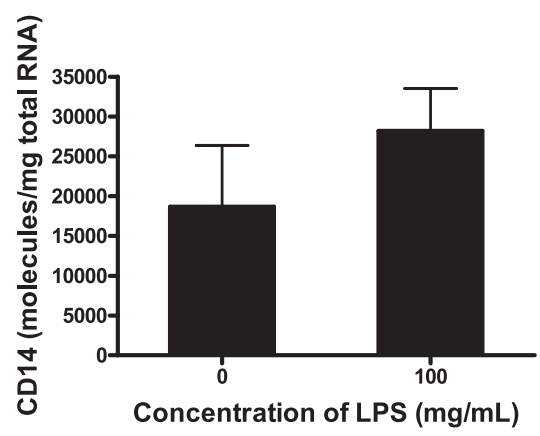

B

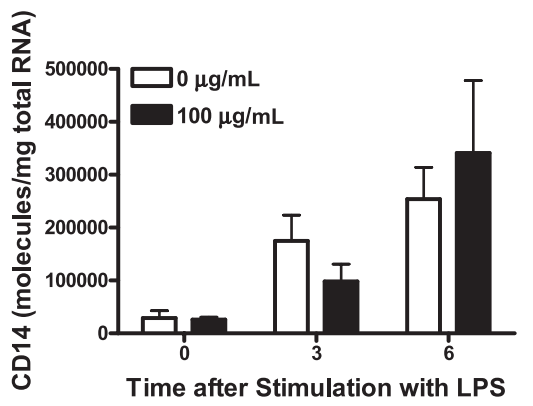

Figure 7. (A) Expression of CD14 mRNA in PMN $\left(5 \times 10^{7} / \mathrm{mL}\right)$ in response to LPS after $30 \mathrm{~min}$ at $37^{\circ} \mathrm{C}(n=2$ cows $)$. (B) Expression of CD14 mRNA in PMN $\left(5 \times 10^{7} / \mathrm{mL}\right)$ in response to LPS after 0,3 , or $6 \mathrm{~h}$ at $37^{\circ} \mathrm{C}(n=3$ cows). For both studies, cells were collected and total RNA was extracted and evaluated by quantitative real-time RT-PCR. Data shown are representative of two individual experiments. Values did not differ from unstimulated PMN $(P>0.05)$. Means \pm SEM.

quarters injected with the recombinant proteins and challenged with Escherichia coli had reduced clinical symptoms, such as mammary swelling and abnormal milk, compared to $E$. coli-challenged quarters injected with saline $[18,25]$. Both recombinant proteins also facilitated the clearance of $E$. coli from the gland when compared to bacterial counts from quarters injected with E. coli plus saline. These results 
suggest that rbosCD14 and PrbosCD14 can be potent prophylactic tools for reducing severity of infection by Gram-negative organisms.

PMN undergo constitutive apoptosis when aged in vitro. Aging PMN exhibit classical features of apoptosis such as cell shrinkage, cytoplasmic condensation, and condensation of nuclear heterochromatin $[24,30]$. In our experiment, we observed that LPS delayed apoptosis. Because $35 \%$ of the isolated PMN used in this study expressed mCD14, they were able to bind LPS resulting in an anti-apoptotic response. LPS has been reported to delay apoptosis in isolated human PMN [17,43]. In contrast, using whole blood, van Oostveldt et al. [40] reported that LPS accelerated bovine PMN apoptosis. Interestingly, in that study PMN apoptosis was induced following intramammary challenge with $E$. coli, but no effect was observed following intramammary injection of LPS [39]. The authors attributed this to the appearance of TNF- $\alpha$, an inducer of apoptosis, in blood after challenge with $E$. coli, that was not present in blood after challenge with LPS. During E. coli-induced mastitis, TNF- $\alpha$ appeared in the circulation between 8 and $16 \mathrm{~h}$ after inoculation, whereas after intramammary injection of $500 \mu \mathrm{g}$ of endotoxin, it was not detected in blood or detected only at low concentrations, compared with concentrations for E. coliinduced mastitis [14,28]. We also observed that the release of CD14 after exposure to LPS was not related to apoptosis. After $6 \mathrm{~h}$ of exposure to LPS, all concentrations of LPS reduced apoptosis, but only the highest concentration induced release of CD14. The decrease in the percentage of apoptotic PMN in control media after $20 \mathrm{~h}$ of incubation (Fig. 1B) when compared to PMN in control media after $6 \mathrm{~h}$ of incubation (Fig. 1A), may have been the result of the dying off of some of the apoptotic PMN observed at $6 \mathrm{~h}$. The death of those PMN may have contributed to the low concentra- tion of CD14 $(3 \mathrm{ng} / \mathrm{mL})$ in control media $(0 \mu \mathrm{g} / \mathrm{mL}$ of LPS $)$ after incubation of PMN for $20 \mathrm{~h}$ (Fig. 2B).

An interesting finding was that the release of CD14 from PMN occurred immediately after stimulation with $100 \mu \mathrm{g} / \mathrm{mL}$ of LPS (Fig. 3), and mimics what was reported to be observed in vivo [15]. After experimental intramammary challenge with LPS, the increase in sCD14 in milk occurred almost immediately after the appearance of somatic cells in milk, and continued to parallel the increase in somatic cell counts in milk [19]. After injection of LPS, $95 \%$ of the somatic cells consist of PMN [29]. Further, the increase in blood serum albumen occurred before the appearance of CD14 in milk, and started to decrease as CD14 started to increase [19], suggesting that the PMN component of the milk somatic cells are the source of CD14 in milk.

Significant findings from the present study are that in addition to bovine monocytes and macrophages, bovine PMN also express CD14 on their cell surface. Further, sCD14 results from the shedding of $\mathrm{mCD} 14$ from bovine PMN, which is accelerated by LPS. These findings are supported by studies that reported high mCD14 expression levels on circulating monocytes and intestinal macrophages derived from patients with Crohn's disease, an inflammatory bowel disease [10], and that mCD14-positive PMN accumulate in the lungs of patients with acute respiratory distress syndrome. The increase in sCD14 was suggested to be associated with the accumulation of PMN at inflammatory sites $[6,19]$. The level of sCD14 was found to be strongly related to the concentration of PMN in the bronchoalveolar lavage from patients with acute lung injury [21] and to the concentration of PMN in milk of cows [19]. LPS induced the release of CD14 from human PMN, and was suggested to originate from the shedding of mCD14 and from an intra- 
cellular pool stored in the granules of PMN [7, 34]. In our flow cytometry study, $100 \mu \mathrm{g} / \mathrm{mL}$ of LPS caused the percentage of PMN expressing mCD14 to decrease, and resulted in a concomitant increase in $\mathrm{SCD} 14$ at the same concentration of LPS (Figs. 2 and 3). Our study also showed that bovine PMN have an intracellular pool of CD14, and that mRNA CD14 expression did not increase after LPS stimulation when compared to unstimulated PMN. This indicates that the source of the sCD14 is mCD14. Soluble CD14 found in human serum has been attributed to the shedding of mCD14 from monocytes, macrophages and PMN [9]. A study by Paape et al. [27] reported that bovine PMN expressed mCD14 after migration into the mammary gland, and that the increase in sCD14 in milk paralleled the increase in milk PMN [18].

This is the first study to provide direct evidence that IL- 8 and IL- $1 \beta$ are secreted by bovine PMN. Purified bovine peripheral blood mononuclear cells were shown to produce an IL-8 like peptide, that possessed chemotactic activity for bovine PMN [12]. Culture supernantants from purified peripheral blood PMN were previously shown to produce IL-1 like cytokines that exhibited IL-1 activity [3]. Locally, IL- 8 and IL-1 $\beta$ promote PMN recruitment to the site of infection by acting as chemoattractants. Further, the release of sCD14 from PMN caused down regulation of IL- 8 secretion but not IL-1 $\beta$ secretion from PMN. Soluble CD14 secretion by LPS treated PMN was increased in parallel with the decrease in IL-8 secretion (Figs. 3 and 5). Further, the increase of sCD14 with increasing concentrations of PMN after stimulation with low doses of LPS (0.1 and $10 \mu \mathrm{g} / \mathrm{mL})$ was also in parallel with the decrease of IL-8 (Figs. 5A, 6B). With higher concentrations of PMN, there would be correspondingly larger pools of available membrane CD14 that could be shed. Thus, we hypothesize that lower concentrations of LPS could evoke enough CD14 shedding to suppress IL-8 production when higher numbers of PMN were stimulated. As demonstrated in Figures 5 and 6, LPS concentrations of 0.1 and $10 \mu \mathrm{g} / \mathrm{mL}$ were able to induce CD14 shedding from PMN in high enough concentration to suppress IL-8 production. Consistent with our hypothesis, increases in cell density corresponded with increased suppression of IL-8. Together, these data suggest that a critical threshold of CD14 needs to be shed, either from a small number of PMNs in response to a high dose of LPS, or from a large number of PMNs in response to a low dose of LPS, in order to suppress IL-8 production. It was reported that production of IL-8 was inhibited via CD14 cleavage by human leukocyte elastase, which might be another mechanism for the down-regulatory cascade of inflammation [13]. Burkholderia cepacia induced IL-8 synthesis in human lung epithelial cells in a CD14 and mitogen activated protein kinase dependent manner [33]. A study by Hatta et al. [13] reported that IL-8 synthesis and release were dramatically reduced at high PMN density.

After experimental intramammary challenge with LPS, IL-8 rapidly increased in milk before the increase in CD14 and appearance of milk somatic cells, and then began to decrease as CD14 started to increase [19]. Because IL-8 in milk preceded the increase in somatic cells suggests that the CD14 released from newly migrated somatic cells (95\% PMN), may also downregulate IL-8 secretion from mammary epithelial and endothelial cells. This negative feedback mechanism reported in this and other studies is to be assumed to result in the inhibition of further PMN recruitment and activation, and contributes to the control of inflammatory functions and excessive tissue damage in vivo. Generation of IL-8 from PMN in other species was previously shown to be regulated by a wide variety of soluble agonists such as IL-4, 
IL-10, IL-13 and INF- $\gamma[16,22,26,45]$ and IL-1 and TNF- $\alpha$ receptors [13].

Although previous studies have used indirect assays to assess cytokine production by bovine PMN, this is the first study to use direct measurement assays (i.e., ELISA's) to establish that these cells are capable of secreting CD14, IL-8, and IL-1 $\beta$. Further, this is the first study to provide evidence that $\mathrm{sCD} 14$ results from shedding of bovine PMN membrane CD14. That suppression of LPS-induced IL-8 secretion was demonstrated to correlate with increased sCD14 suggests a potential role for sCD14 in limiting an exaggerated inflammatory response by down-regulating expression of a potent chemoattractant. Further studies, however, will be needed in order to establish a cause and effect relationship between sCD14 shedding and down-regulation of IL-8 production.

\section{REFERENCES}

[1] Baggiolini M., Chemokines and leukocytes traffic, Nature (1998) 392:565-568.

[2] Burvenich C., Paape M.J., Hill A.W., Guidry A.J., Miller R.H., Heyneman R., Kremer W.D., Brand A., Role of the neutrophil leukocyte in the local and systemic reactions during experimentally induced $E$. coli mastitis in cows immediately after calving, Vet. Q. (1994) 16:45-50.

[3] Canning P.C., Neill J.D., Isolation and characterization of interleukin-1 from bovine polymorphonuclear leukocytes, J. Leukoc. Biol. (1989) 45:21-28.

[4] Cassatella M.A., The production of cytokines by polymorphonuclear neutrophils, Immunol. Today (1995) 16:21-26.

[5] Cassatella M., Gasperini S., Russo M.P., Cytokine expression and release by neturophils, Ann. NY Acad. Sci. (1997) 832:233-242.

[6] Cauwels A., Frei K., Sansano S., Fearns C., Ulevitch R., Zimmerli W., Landmann R., The origin and function of soluble CD14 in experimental bacterial meningitis, J. Immunol. (1999) 162:4762-4772.
[7] Detmers P.A., Zhou D., Powell D., Lichenstein H., Kelley M., Pironkova R., Endotoxin receptors (CD14) are found with CD16 (Fc gamma RIII) in an intracellular compartment of neutrophils that contains alkaline phosphatase, J. Immunol. (1995) 15:2085-2095.

[8] Duriex J.J., Vita N., Popescu O., Guette F., Calzada-Wack J., Munker R., Schmidt R.E., Lupker J., Ferrara P., Ziegler H.W., Labeta M.O., The two soluble forms of the lipopolysaccharide receptor, CD14: Characterization and release by normal human monocytes, Eur. J. Immunol. (1994) 24:2006-2012.

[9] Freyer E.A., Miller D.S., Jahr T.G., Sundan A., Bazil V., Espevik T., Finlay B.B., Wright S.D., Soluble CD14 participates in the response of cells to lipopolysaccharide, J. Exp. Med. (1992) 176:1665-1671.

[10] Grimm M.C., Pavli P., van de Pol E., Doe W.F., Evidence for a $\mathrm{CD} 14^{+}$population of monocytes in inflammatory bowel disease mucosa: implications for pathogenesis, Clin. Exp. Immunol. (1995) 100:291-297.

[11] Hahn G., Tolle A., Comparative studies to characterize human and bovine group Bstreptococci (Str. agalactiae) by means of a bactericidal assay, Zentralbl. Bakteriol. A (1981) 249:15-23.

[12] Hassfurther R.L., Canning P.C., Geib R.W., Isolation and characterization of an interleukin-8-like peptide in the bovine species, Vet. Immunol. Immunopathol. (1994) 42:117-126.

[13] Hattar K., Fink L., Fietzner K., Himmel B., Grimminger F., Seeger W., Sibelius U., Cell density regulates neutrophil IL-8 synthesis: role of IL-1 receptor antagonist and soluble TNF receptors, J. Immunol. (2001) 166:6287-6293.

[14] Hoeben D., Burvenich C., Trevisi E., Bertoni G., Hamman J., Blum J.W., Role of endotoxin and $\mathrm{TN}-\alpha$ in the pathogenesis of experimentally induced coliform mastitis in periparturient cows, J. Dairy Sci. (2000) 67:503-514.

[15] Jain N.C., Paape M.J., Miller R.H., Use of flow cytometry for determination of differential leukocyte counts in bovine blood, Am. J. Vet. Res. (1991) 52:630-636.

[16] Kasama T., Strieter R.M., Lukacs N.W., Burdick M.D., Kunkel S.L., Regulation of 
neutrophil-derived chemokine expression by IL-10, J. Immunol. (1994) 152:3559-3569.

[17] Lee A., Whyte M.K.B., Haslett C., Inhibition of apoptosis and prolongation of neutrophil function longevity by inflammatory mediators, J. Leukoc. Biol. (1993) 54:283-288.

[18] Lee J.W., Paape M.J., Elsasser T.H., Zhao X., Recombinant soluble CD14 reduces severity of intramammary infection by Escherichia coli, Infect. Immun. (2003) 71:4034-4039.

[19] Lee J.W., Paape M.J., Elsasser T.H., Zhao X., Elevated Milk Soluble CD14 in bovine mammary gland challenged with Escherichia coli lipopolysaccharide, J. Dairy Sci. (2003) 86:2282-2289.

[20] Maliszewski C.R., CD14 and immune response to lipopolysaccharide, Science (1991) 252:1231-1322.

[21] Martin T.R., Rubenfeld G.D., Ruzinski J.T., Goodman R.B., Steinberg K.P., Leturcq D.J., Moriarty A.M., Raghu G., Baughman R.P., Hudson L.D., Relationship between soluble CD14, lipopolysaccharide binding protein, and the alveolar inflammatory response in patients with acute respiratory distress syndrome, Am. J. Respir. Crit. Care Med. (1997) 155:937-944.

[22] Meda L., Gasperini S., Ceska M., Cassatella M.A., Modulation of proinflammatory cytokines release from human polymorphonuclear leukocytes by $\gamma$ interferon, Cell. Immunol. (1994) 157:448-461.

[23] Medzhitow R., Preston-Hurlburt P., Janeway C.A. Jr., A human homologue of the Drosophila Toll protein signals activation of adaptive immunity, Nature (1997) 24:394-397.

[24] Mollinedo F., Borregaard N., Boxer L.A., Novel trends in neutrophil structure, function and development, Immunol. Today (1999) 20:535-537.

[25] Nemchinov L.G., Paape M.J., Sohn E.J., Bannerman D.D., Zarlenga D.S., Hammond R.W., Bovine CD14 receptor produced in plants reduces severity of intramammary bacterial infection, FASEB J. (2006) 20:1345-1351.

[26] Nemoto E., Sugawara S., Tada H., Takada H., Shimauchi H., Horiuchi H., Cleavage of CD14 on human gingival fibroblasts cocultured with activated neutrophils is mediated by human leukocyte lipopolysaccharide- induced IL-8 production, J. Immunol. (2000) 15:5807-5813.

[27] Paape M.J., Lilius E.M., Wiitanen P.A., Kontio M.P., Miller R.H., Intramammary defense against infections induced by Escherichia coli in cows, Am. J. Vet. Res. (1996) 4:477-482.

[28] Paape M.J., Rautiainen P.M., Lillius E.M., Malstrom C.E., Elsasser T.H., Development of anti-bovine TNF- $\alpha$ mAb and ELISA for quantitating TNF- $\alpha$ in milk after intramammary injection of endotoxin, J. Dairy Sci. (2002) 85:765-773.

[29] Paape M.J., Bannerman D.D., Zhao X., Lee J.W., The bovine neutrophil: Structure and function in blood and milk, Vet. Res. (2003) 34:597-627.

[30] Payne C.M., Glasser L., Tischler M.E., Wyckoff D., Cromey D., Fiederlein R., Bohnert O., Programmed cell death of the normal human neutrophil: An in vitro model of senescence, Microsc. Res. Tech. (1994) 28:327-344.

[31] Peveri P., Walz A., Dewald B., Baggiolini M., A novel neutrophil activating factor produced by human mononuclear phagocytes, J. Exp. Med. (1998) 167:1547-1559.

[32] Phillips H.J., Dye exclusion test for cell viability, in: Kruse P.F. Jr., Patterson M.J. (Eds.), Tissue culture methods and application, Academic Press Inc., New York, 1973, pp. 406-408

[33] Reddi W., Phagoo S.B., Anderson K.D., Warburton D., Burkholderia cepaciainduced IL-8 gene expression in an alveolar epithelial cell line: signalling through CD14 and mitogen -activated protein kinase, Pediatr. Res. (2003) 54:297-305.

[34] Rodeberg D.A., Morris R.E., Babcock G.F., Azurophilic granules of human neutrophils contain CD14, Infect. Immun. (1997) 65:4747-4753.

[35] Schutt C., Schilling T., Grunwald U., Schonfeld W., Kruger C., Endotoxin neutralizing capacity of soluble CD14, Res. Immunol. (1992) 143:71-78.

[36] Seiler P., Aichele P., Raupach B., Odermatt B., Steinhoff U., Kaufmann H.E., Rapid neutrophil response controls fast-replicating intracellular bacteria but not slow-replicating Mycobacterium tuberculosis, J. Infect. Dis. (2000) 181:67-80. 
[37] Shuster D.E., Lee E.K., Kehrli M.E., Bacterial growth, inflammatory cytokine production and neutrophil recruitment during coliform mastitis in cows within ten days after calving, compared with cows at midlactation, Am. J. Vet. Res. (1996) 57:1569-1575.

[38] Shuster D.E., Kehrli M.E., Rainard P., Paape M.J., Complement fragment C5a and inflammatory cytokines in neutrophil recruitment during intramammary infections with Escherichia coli, Infect. Immun. (1997) 65:3286-3292.

[39] Sohn E.J., Paape M.J., Peters R.R., Fetterer R.H., Talbot N.C., Bannerman D.D., The production and characterization of antibovine CD14 monoclonal antibodies, Vet. Res. (2004) 35:597-608.

[40] Van Oostveldt K., Paape M.J., Dosogne H., Burvenich C., Effect of apoptosis on phagocytosis, respiratory burst and CD18 adhesion receptor expression of bovine neutrophils, Domest. Anim. Endocrinol. (2002) 22:37-50.
[41] Wang Y., Zarlenga D.S., Paape M.J., Dahl G.E., Recombinant bovine soluble CD14 sensitizes the mammary gland to lipolysaccharide, Vet. Immunol. Immunopathol. (2002) 86:115-124.

[42] Wang Y., Zarlenga D.S., Paape M.J., Dahl G.E., Tomita G.M., Functional analysis of recombinant bovine CD14, Vet. Res. (2003) 34:413-421.

[43] Watson R.W.G., Redmond H.P., Wang J.H., Bouchier-Hayes D., Bacterial ingestion, tumor necrosis factor-alpha, and heat induce programmed cell death in activated neutrophils, Shock (1996) 5:47-51.

[44] Weiss S.J., Mechanisms of disease: tissue destruction by neutrophils, N. Engl. J. Med. (1989) 320:365-376.

[45] Wertheim W.A., Kunkel S.L., Standford T.J., Burdick M.D., Becker F.S., Wilke C.A., Gilbert A.R., Strieter R.M., Regulation of neutrophil-derived IL-8: the role of prostaglandin $\mathrm{E}_{2}$, dexamethasone, and IL-4, J. Immunol. (1993) 151:2166-2175. 